\title{
33-Özel gereksinimli bireylerin dil gelişim süreçleri ile ilgili yapılan lisansüstü tezlerin analizi
}

İsmail EROL ${ }^{1}$

\section{Gökçen ILHAN ILDIZ ${ }^{2}$}

\begin{abstract}
APA: Erol, İ; İlhan Ildız, G. (2020). Özel gereksinimli bireylerin dil gelişim süreçleri ile ilgili yapılan lisansüstü tezlerin analizi. (2000-2019). RumeliDE Dil ve Edebiyat Araşttrmaları Dergisi, (21), 559-574. DOI: 10.29000/rumelide.843486.
\end{abstract}

\section{$\ddot{\mathbf{O} z}$}

Özel eğitim; yetersizliklerin engele dönüşmesini önleyen, bireylerin toplum içerisinde bağımsız bir şekilde yaşamasını sağlayan ve sosyal yönden gelişmelerini amaçlayan, becerilerini geliştiren hizmetlerin tümünü kapsamaktadır. Bu hizmetlerden en önemlisi hiç şüphesiz ki dil gelişimidir. Çünkü dil; bireyleri ve toplumları birbirine bağlayan, iletişimi başlatan ve sürdüren, insanların bă̆ kurmasını sağlayan önemli bir araçtır. Bu araştırmanın amacı Türkiye'de özel gereksinimli bireylerin dil gelişim süreçleri ile ilgili yapılan lisansüstü tezlerin farklı değişkenler açısından incelenmesidir. Yükseköğretim Kurulu tez arama merkezinde “özel eğitimde dil gelişimi” koduyla gerçekleştirilen aramalarda 11 doktora, 54 yüksek lisans tezi ve 4 tıpta uzmanlık tezi olmak üzere toplamda 69 teze ulaşılmıştır. Araştırmanın çalışma grubunu 69 tez oluşturmaktadır. Araştırma nitel araştırma yöntemlerinden doküman analizi ile gerçekleştirilmiştir. Verilerin analizinde beş aşamalı doküman analizi tekniği kullanılmıştır. Araştırma sonuçlarında; lisansüstü tezlerde en çok tezin 2016'da yazılmış olduğu, eğitim düzeylerine göre 54 tez ile en çok yüksek lisans tezinin olduğu, yazıldıkları dil açısından 62 tezle en çok Türkçe, tez danışmanları bağlamında en fazla Profesör ve Dr. Öğr. Üyesi olduğu ortaya çıkmıştır. Tez danışmanlarının cinsiyetleri bağlamında 41 kadın; tez yazarlarının cinsiyetleri bağlamında ise 51 kadın olduğu belirlenmiştir. Tezlerin yazıldıkları üniversitelere bakıldığında en fazla Hacettepe ve Ankara Üniversitesi, enstitüler bağlamında en fazla sağlık bilimleri enstitüleri, anabilim dalları bağlamında ise en çok özel eğitim anabilim dallarında tez yazıldığı ortaya çıkmıştır. Tezlerin araştırma yöntemlerine bakıldığında en fazla nicel yöntemlerin tercih edildiği, araştırma modeli bağlamında en çok tarama modelinin kullanıldığı, ele alınan özel eğitim alanına göre işitme engelliler yönünde ağır bastığı ve konular bağlamında ise davranış becerileri gelişim değerlendirmesinin en fazla seçilen konu olduğu görülmektedir.

Anahtar kelimeler: Dil gelişimi, eğitim, özel eğitim, özel gereksinimli bireyler, lisansüstü tezler

\section{Examination of theses conducted on language development processes of individuals with special needs}

\footnotetext{
Abstract

Special education includes all services that prevent disabilities from turning into obstacles, enable individuals with special needs to live independently in the society and develop their skills to socialize. The most important of these services is language development. Language is an important ismailerol@nku.edu.tr, ORCID ID: 0000-0001-8531-6001 [Araştırma makalesi, Makale kayıt tarihi: 20.11.2020-kabul tarihi: 20.12.2020; DOI: 10.29000/rumelide.843486]

2 Öğgr. Gör., Namık Kemal Üniversitesi, Sağllk Hizmetleri MYO, Çocuk Gelişimi Bölümü (Tekirdağ, Türkiye), gildiz@nku.edu.tr, ORDCID ID: 0000-0002-2091-5270

Adres | Address

İstanbul Medeniyet Üniversitesi, Eğitim Bilimleri Fakültesi, Türkçe ve Sosyal Bilimler Eğitimi Bölümü, Türkçe Eğitimi ABD Cevizli Turkish and Social Scinces Education, Turkish Language Teaching Kampüsü, Kartal-İstanbul/TÜRKIYE Education, Cevizli Campus, Kartal-İstanbul /TURKEY e-posta: editor@rumelide.com $\mid$ e-mail: editor@rumelide.com
} 
tool that connects individuals and societies, initiates and maintains communication, and enables people to communicate. The purpose of this research is to examine the different variables of postgraduate thesis conducted in the field of language development of individuals with special needs in Turkey. A total of 69 theses including 11 doctorates, 54 master's theses and 4 specialty theses in medicine were found in the searches conducted in the Higher Education Council's thesis search center with the code "language development in special education". 69 theses constitute the universe of the research. The research was carried out with document analysis method which is one of the qualitative research methods. Five-step document analysis technique was used in the analysis of the data. Results show that, most of the graduate theses were written in 2016, a maximum of 54 theses were written at the graduate level according to their education level, a maximum of 62 theses were written in Turkish in terms of the language, a maximum of 23 theses' advisors were professor and assistant professor. 41 women supervisors and 51 women writers were determined in terms of the gender. Considering the universities where the theses were written, it is seen that theses were written mostly in Hacettepe and Ankara University and in the context of the institute and department, it is found that health sciences, special education department were the fields theses written most. When the research methods of the theses are examined, it is seen that the quantitative method is preferred the most, the scanning model is used in the context of the research model, and the theses in the direction of the hearing impaired are dominant according to the special education field. In the context of subjects, it is seen that behavioural skills development assessment is the most chosen subject in theses.

Keywords: Language development, education, special education, special needs, postgraduate thesis

\section{Giriş}

Dil gelişimi, normal gelişim gösteren bireylerde önemli olduğu kadar, özel gereksinimli bireylerde de elzemdir. Dilin ne anlama geldiği ve gelmediği ile ilgili farklı görüşler ileri sürülmek ile birlikte, yapılan analizlerde dil konusunun, antropoloji, felsefe, mantık, sosyoloji, dil psikolojisi, dilbilim, göstergebilim ve dil sosyolojisi alanları üzerine değişik yaklaşımlar ile incelendiği görülür (Yapıcı, 2006). Özellikle yaşıtlarından belirli düzeyde anlamlı farklılıklar gösteren özel gereksinimli bireylerin; konuşabilme, kendini ifade edebilme ve iletişim kurabilme yetenekleri tamamen dil gelişim süreçleri üzerine odaklıdır. Kendilerini ifade edebilen, ihtiyaçlarını gidermek için iletişim kurabilen, akranları ve sosyal çevresi ile sözlü bağ kurabilen özel gereksinimli bireyler, kendilerini gerçekleştirme yolunda önemli bir adım atmış olacaklardır. Unutulmamalıdır ki, özel gereksinimli bireylerin kendi ayakları üzerinde durabilmeleri için bazı "zorunlu" ihtiyaçları vardır. Bu ihtiyaçlardan en ivedi ve gerekli olanları şüphesiz ki; dil gelişim süreçlerini tamamlamaları, aileleri, akranları, yakın çevreleri ve bakımları ile ilgilenenlerle iletişim kurabilir bir seviyeye gelmeleridir. Bu sebep ile ilk önce dil ve dil gelişimi kavramlarından bahsetmekte fayda görülmektedir.

Dil, bireyler arası iletişim süreçlerini başlatma, düşünce ve duyguların aktarılmasını sağlama adına anlamlı kelimelerin bir bütüne toplanmasıdır (Temel, Bekir ve Yazıcı, 2014). Dil aynı zamanda insanların ihtiyaçlarına göre oluşturdukları ve geliştirdikleri toplumsal bir kurumdur (Vendryes, 2001, s. 14). Harley (2001, s. 20-22) dili, insanlığın ne anlam ifade ettiğini ve insanları farklı kılan bir terim olarak açıklamakta, düşünce ve dilin birbirine bağlı olduğunu dile getirmektedir. Dil, bilişsel alandaki gelişimler ile paralel bir şekilde meydana gelir. Her bireyin bilişsel süreçleri birbirinden farklı olduğundan dil gelişimi süreçlerinde de farklılıklar bulunabilmektedir. Çünkü bireylerin zihinsel

Adres

İstanbul Medeniyet Üniversitesi, Eğitim Bilimleri Fakültesi, Türkçe ve Sosyal Bilimler Eğitimi Bölümü, Türkçe Eğitimi ABD Cevizli Kampüsü, Kartal-İstanbul/TÜRKIYY e-posta: editor@rumelide.com
Address

Istanbul Medeniyet University, Faculty of Education Sciences,

Turkish and Social Scinces Education, Turkish Language Teaching

Education, Cevizli Campus, Kartal-İstanbul /TURKEY

e-mail: editor@rumelide.com 
durumları ve yetenekleri dile de yansımaktadır. Dil gelişimi alanında çalışmalar gerçekleştiren Vygotsky (1985, s. 17-20), düşünce ve dilin kendi içlerinde bağımsız gibi göründüğünü ama birbirleri ile paralel bir şekilde geliştiklerini dile getirmektedir. İlk süreçlerde bağımsız olan düşünce ve dil zamanla birbirlerine bağlanmaktadırlar. Vygotsky, dil öğretimi ve eğitiminin çocukların zihinsel düşünme yeteneklerini etkilediğini dile getirir. Öyle ise özel gereksinimli bireylerin, akranları ile aralarında var olan hem sosyal hem de akademik beceri ve gelişim farklarını en aza indirebilmek adına bu bireylerin dil gelişimlerinin desteklenmesi gerekmektedir.

Dilin kullanımı bireylerin bilişsel ve sosyal gelişimleri açısından gereklidir (Özbay ve Melanlıŏlu, 2008). Öyle ki, bireyler eğer dili amacına uygun, nitelikli ve etkin bir şekilde kullanmaz ise zaman içerisinde akademik ve sosyal yönden yaşıtlarından eğitim boyutunda geride kalmaktadırlar. Yaşamsal faaliyetlerin her boyutunda kullanılmakta olan dilin, okul öncesi dönemlerden başlayarak yeterli bir biçimde desteklendiği takdirde, bireylerin yaşamları boyunca, sosyal ve akademik gelişimlerini olumlu bir şekilde etkileyeceğini bilinmektedir (Aydoğan ve Koçak, 2003).

Dil gelişiminin tanımına bakıldığında ise; kelimeler, sayılar ve sembollerin öğrenilmesi, hafızada saklanması ve dilin kurallara uygun bir biçimde kullanılması süreci olarak ifade edilmektedir (Kayıll, Koçyiğit ve Erbay, 2009). Yine dil gelişimi; çocukların bilişsel, duygusal ve sosyal gelişim süreçlerini etkileme adına önemlidir. Aynı zamanda dil gelişimi, çocukların toplumsallaşması, düşünme becerilerini geliştirmesi, kavram geliştirme süreçlerini etkilemesi, problem çözebilme ve ilişki kurabilme ile bilişsel alanda gelişim süreçlerinde de etkilidir. Özetle dil gelişimi; sayılan diğer gelişim alanları ile etkileşimdedir ve ilerleme gelişimsel bir bütünlük içerisinde olmaktadır (Senemoğlu, 1989).

Özel gereksinimi olan bireyler 573 sayılı Özel Eğitim Hakkında Kanun Hükmünde Kararname içerisinde (1997) özel eğitim ihtiyacı olan bireyler başlı̆̆ı altında: "çeşitli sebepler neticesinde, eğitim yeterlilikleri ve bireysel özellikler bağlamında yaşıtları ile kıyaslandığından anlamlı farklılıklar göstermekte olan birey" olarak ifade edilmektedir. Özel gereksinimleri bulunan bireylerin, davranışsal özellikleri ve öğretme-öğrenme süreçleri bağlamında hem diğer insanlardan hem de kendi içlerinde bir takım farklılıklar sergilemeleri beklenen bir sonuçtur. Bu farklılıklar genellikle fiziksel boyutta ortaya çlkabileceği gibi; zihinsel boyutta, görme ve işitme duyusunda, süreğen hastalıklar ile beraber, konuşma ve dil gelişimi problemleri şeklinde de ortaya çıkabilir (Yaralı, 2015). Özellikle Türkiye'de özel gereksinimleri bulunan bireyler ve bu bireylerin dil gelişimlerinin takip edilmesi gittikçe önem kazanan ve üzerinde durulması gereken bir eğitim konusu haline gelmiştir. Dolayısıyla özel gereksinimleri bulunan bireylerin dil gelişim süreçleri üzerine gerçekleştirilen lisansüstü tezlerin incelenmesi elzem bir hal almıştır. Yine dilin tanımında, konuşma ile iletişimin sürekli gerçekleştirildiği ortamlarda geliştiği ifade edilmektedir. Çocuklar dillerini, diğer insanlar ile ilişki kurmak suretiyle öğrenirler. Dil, diğer öğrenmelerin gerçekleşmesi için gerekir (Gönen ve Arı, 1989). Özel gereksinimli bireylerin gelişim süreçlerinde de dil önemli bir unsurdur. Günümüzde özel gereksinimleri bulunan bireylerin sayılarına bakıldığında, Dünya Sağlı Örgütü’nün ortaya koyduğu standartlar kabul edilmektedir. Bu standartlara göre ülkelerin nüfuslarının \%10 ila \%12 arasındaki oranının özel gereksinimli bireylerden oluştuğu ifade edilmektedir (Baykoç Dönmez, 2010, s. 338).

Dünya Sağlık Örgütü'nün beyanlarında özel gereksinimli bireylerin ülke nüfusları içerisindeki yüzdesi azımsanmayacak kadar yüksektir. Bu sebep ile özel gereksinimli bireylerin dil gelişim süreçleri ile yapılan lisansüstü tezlerin incelenmesinin; hem dil gelişimi alanına hem de özel eğitim alanına faydalı olacağı düşünülmektedir. Bu araştırmada, özel gereksinimli bireylerin dil gelişim süreçleri ile ilgili yapılan lisansüstü tezlerin incelenmesi amaçlanmıştır. Kendilerini ifade etmekte güçlük çeken,

\footnotetext{
\begin{tabular}{r|l} 
Adres & $\begin{array}{l}\text { Address } \\
\text { İstanbul Medeniyet Üniversitesi, Eğitim Bilimleri Fakültesi, Türkçe }\end{array}$ \\
İstanbul Medeniyet University, Faculty of Education Sciences,
\end{tabular}

ve Sosyal Bilimler Eğitimi Bölümü, Türkce Eğitimi ABD Cevizli Turkish and Social Scinces Education, Turkish Language Teaching Kampüsü, Kartal-İstanbul/TÜRKIYE Education, Cevizli Campus, Kartal-İstanbul /TURKEY e-posta: editor@rumelide.com $\mid$ e-mail: editor@rumelide.com
} 
toplumdaki diğer bireyler ile iletişim kurma problemleri yaşayan ve özbakım gereksinimlerini bile dile getirmekte güçlük yaşayabilen özel gereksinimli bireyler düşünüldüğünde alanda yapılan lisansüstü tezlerinin ayrıntılı bir şekilde analiz edilmesi önemlidir. Bu analizlerin hem eğitimcilere, hem ailelere hem de alandaki diğer özel eğitim ve dil gelişimi paydaşlarına yol gösterici olması beklenmektedir. Bu amaç ışığında aşağıdaki sorulara cevaplar aranmıştır:

1. Tezlerin yazıldıkları yıllara göre dağılımları nasıldır?

2.Tezlerin eğitim düzeyine göre dağılımları nasıldır?

3. Tezlerin yazıldıkları dillere göre dağılımları nasıldır?

4. Tez danışmanlarının unvanlarına göre dă̆ılımları nasıldır?

5. Tez danışmanlarının cinsiyetine göre dağılımları nasıldır?

6. Tez yazarlarının cinsiyetine göre dağılımları nasıldır?

7. Tezlerin yazıldıkları üniversitelere göre dağılımları nasıldır?

8. Tezlerin yazıldıkları enstitülere göre dağılımları nasıldır?

9. Tezlerin yazıldıkları anabilim dalına göre dağılımları nasıldır?

10. Tezlerin yazımında kullanılan araştırma yöntemlerine göre dağılımları nasıldır?

11. Tezlerin yazımında kullanılan araştırma modellerine göre dağılımları nasıldır?

12. Tezlerin ele alınan özel gereksinim gruplarına göre dağılımlar nasıldır?

13. Tezlerin ele alınan konulara göre dağılımlar nasıldır?

\section{Yöntem}

$\mathrm{Bu}$ araştırmada, verilerin detaylı bir şekilde incelendiği ve veriler arasında meydana gelen bağlantıların analiz edildiği "nitel araştırma yöntemi" kullanılmıştır. Nitel araştırmalar gözlem, görüşme, doküman analizi gibi veri toplama yöntemlerinin kullanılarak araştırılan durumun gerçekçi bir şekilde ortaya koymayı amaçladığı yöntemdir” (Ylldırım ve Şimşek, 2013, s. 259). Bu araştırmada bazı kriterler doğrultusunda analizler gerçekleştirilmiştir. Bu kriterler tezlerin yazılmış oldukları yıllar, tezlerin yazıldıkları eğitim düzeyleri ve diller, tez danışmanlarının cinsiyeti ve unvanları, tez yazarlarının cinsiyetleri, tezlerin yazıldığı üniversiteler, enstitüler ve anabilim dalları, tezlerde kullanılan yöntem ve araştırma modelleri, tezlerde ele alınan özel gereksinim grupları ve konulardır.

\section{Araşturmanın modeli}

Bu araştırmada nitel araştırma yöntemlerinden olan "doküman analizi” kullanılmıştır. Doküman analizlerinde araştırılması planlanan olgulara yönelik bilgileri içeren yazılı kaynakların incelenip analiz edilmesi, araştırmacı tarafından gözlem ya da görüşmeler gerçekleştirilmeden sağlanır (Yıldırım ve Şimşek, 2013). Araştırmaların amacına uygun kaynaklara erişmede ve elde edilebilecek verilerin belirlenmesinde kullanılan bu yöntemde, çalışılacak konu ile ilgili basılı ve yazılı kaynakların analizi yapılmaktadır (Yıldırım ve Şimşek, 2013). Bu araştırmada, belirli niteliğe sahip olan tezler inceleneceği için "ölçüt örnekleme yöntemi” kullanılmıştır. Bu teknikte örneklem grupları oluşturulurken, araştırma amaçlarına uygun belirlenmiş ölçütler bağlamında seçimler yapılır. (Büyüköztürk vd, 2010). Araştırmanın amacı doğrultusunda belirlenen bu ölçütler ise, "tezlerin ulaşılabilir olması", "özel gereksinimli bireylerin dil gelişimleri ile ilgili olması" ve "özel gereksinimli bireylerin dil eğitimleri ile ilgili olması" olmak üzere 3 başlıktan oluşmaktadır. Doküman incelemesinde içerik analizi ve genel tarama metodu olmak üzere 2 farklı türü bulunmaktadır. İçerik analizi belirlenmiş bazı belgelerin ya

\footnotetext{
Adres $\mid$ Address

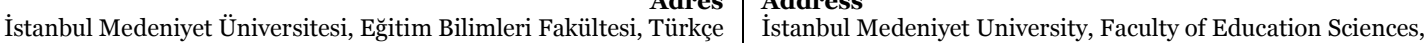
ve Sosyal Bilimler Eğitimi Bölümü, Türkçe Eğitimi ABD Cevizli Turkish and Social Scinces Education, Turkish Language Teaching Kampüsü, Kartal-İstanbul/TÜRKIYE Education, Cevizli Campus, Kartal-İstanbul /TURKEY e-posta: editor@rumelide.com $\mid$ e-mail: editor@rumelide.com
} 
da kitapların belirlenmiş bazı özelliklerini sayısallaştırıp ortaya çıkarmak amacı ile gerçekleştirilir (Karasar, 2009).

\section{Çalışma grubu}

$\mathrm{Bu}$ araştırmanın çalışma grubunu oluşturmak için "YÖK Ulusal Tez Merkezi" internet sayfasından yararlanılmıştır. Ölçüt olarak "özel eğitimde dil gelişimi” belirlenmiş ve 1983 yllı ve 2020 yllı dâhil olmak üzere bu alanda yazılan tezlere "YÖK Ulusal Tez Merkezi" veri tabanından ulaşılmıştır. Gerçekleştirilen taramalar ve belirlenen ölçütler doğrultusunda 69 lisansüstü tezi araştırmaya dâhil edilmiştir. Bu tezlerden 11 adedi doktora düzeyinde, 54 adedi yüksek lisans düzeyinde ve 4 adedi ise tıpta uzmanlık düzeyinde yazılmış tezlerdir.

\section{Veri toplama araçları}

$\mathrm{Bu}$ araştırmada veriler, araştırmacılar tarafından hazırlanmış ve eğitim bilimlerinde uzman dört akademisyen görüşünün alındığı 13 maddelik tez analiz formu kullanılarak elde edilmiştir. Veriler, "YÖK Ulusal Tez Merkezi" veri tabanı kullanılarak toplanmıştır. Özel gereksinimli bireylerin dil gelişim süreçleri ile ilgili olmak kaydı ile bu tezlerin "tezlerin ulaşılabilir olması", "özel gereksinimli bireylerin dil gelişimleri ile ilgili olması" ve "özel gereksinimli bireylerin dil eğitimleri ile ilgili olması" kriter olarak belirlenmiş ve erişim izni olmayan tezler değerlendirme kapsamına alınmamıştır.

\section{Verilerin analizi}

$\mathrm{Bu}$ araştırmanın verilerin analizinde 5 aşamalı doküman analiz tekniği kullanılmıştır. Verilerin analizinde takip edilen aşamalar sırasıyla dokümanlara ulaşmak, özgünlüğü kontrol etmek, dokümanları anlamak, verileri analiz etmek ve verileri kullanmaktır (Forster, 1995; akt. Yıldırım ve Şimşek, 2013). Bu araştırmada Türkiye'de özel gereksinimli bireylerin dil gelişim süreçleri alanında yazılmış lisansüstü tezlerden, doküman inceleme teknikleri ile elde edilmiş olan veriler farklı özellikler kapsamında yüzdeler ve frekansların hesaplanması ile yorumlanmış ve analiz edilmiştir.

\section{Geçerlik ve güvenirlik}

Araştırmanın geçerlik ve güvenirliğini sağlamak adına araştırmacılar tarafından şu uygulamalar gerçekleştirilmiştir. Strauss ve Corbin (1990) araştırmalarında verilerin kodlanması aşamasında 3 türlü yaklaşımın izlenebileceğini dile getirmektedirler. Bu yaklaşımların; "daha öncelerde belirlenen başlıklara göre gerçekleştirilen kodlamalar, verilerin ışığında elde edilen başlıklara göre gerçekleştirilen kodlamalar ve geniş bir çerçevede gerçekleştirilen kodlamalar” olduğu görülür. Bu araştırmada ise "daha öncelerde belirlenen başlıklara göre gerçekleştirilen kodlama biçimi" kullanılmıştır. İlk önce tüm tezler bağımsız 2 araştırmacı tarafından 13 maddelik tez analiz formu kullanılarak kodlanmıştır. Sonrasında ise bu kodlar incelenmiş ve tekrarlanan kodların kullanılması engellenmiştir. Düzenlemesi yapılan ve ortaya konan kategoriler, araştırma bulgularındaki temelleri oluşturmaktadır. Bu sebeple kategorilerde betimsel istatistikî bilgilere yer verilmektedir. Betimsel istatistikî bilgiler frekans analizleri kullanılmak sureti ile çözümlenmektedir. Frekans analizlerinde sayılabilir niteliğe sahip olan birimler alınıp, analizlerin göstergesi olan frekanslar görülme sıklığını ortaya koymaktadır (Turan, Karadă̆, Bektaş \& Yalçın, 2014). Elde edilen bulguları yorumlamak adına tablolardan istifade edilmiştir. Araştırmanın geçerlik ve güvenirliğini sağlamak adına ek önemler de sağlanmıştır. Araştırmada iç geçerliği arttırmak adına kodlamalar ve kategoriler arasındaki ilişkiler araştırmacılar tarafından kontrol edilmiştir. Kategoriler oluşturulurken, ilgili kavramları kapsayacak

\section{Adres | Address}

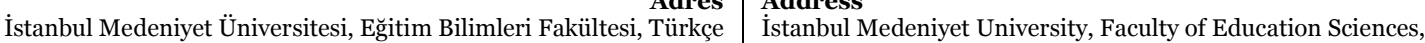

ve Sosyal Bilimler Eğitimi Bölümü, Türkçe Eğitimi ABD Cevizli Turkish and Social Scinces Education, Turkish Language Teaching

Kampüsü, Kartal-İstanbul/TÜRKIYE $\quad$ Education, Cevizli Campus, Kartal-İstanbul /TURKEY e-posta: editor@rumelide.com 1 e-mail: editor@rumelide.com 
kadar genel ama ilgisiz kavramları da kapsamın dışında tutacak kadar dar biçimde oluşturulmasına gayret edilmiştir. İç güvenirliği arttırmak amacıyla da verileri analiz ederken eğitim bilimleri alanında kullanılan bilimsel terimler ele alınıp kategoriler ortaya konmuş ve en az 2 araştırmacı aracıllı̆ı ile kodlama yapılarak karşılaştırmalar yapılmıştır.

\section{Bulgular}

Araştırmanın bu bölümünde analizler sonucunda elde edilen bulgular 1. ve 13. tablolar arasında sunulmuştur. Sunulan tablolar sırası ile tezlerin yazıldıkları yıllara göre dağılımı, tezlerin eğitim düzeyine göre dağılımı, tezlerin yazıldığı dillere göre dağılımı, tezlerin tez danışmanlarının unvanlarına göre dağılımı, tezlerin tez danışmanlarının cinsiyetine göre dağılımı, tezlerin tez yazarlarının cinsiyetine göre dağılımı, tezlerin yazıldığı üniversitelere göre dağılımı, tezlerin yazıldığı enstitülere göre dağılımı, tezlerin yazıldığı anabilim dallarına göre dağılımı, tezlerde kullanılan araştırma yöntemlerine göre dağılımı, tezlerde kullanılan araştırma modellerine göre dağılımı, tezlerde ele alınan özel gereksinim gruplarına göre dağılımı ve tezlerde ele alınan konuya göre dağılımıdır.

Tablo 1. Tezlerin yazıldıkları yıllara göre dağılımları

\begin{tabular}{|c|c|c|c|c|c|}
\hline Yil & $\mathbf{f}$ & $\%$ & Yil & f & $\%$ \\
\hline 2016 & 12 & 17.4 & 2020 & 3 & 4.3 \\
\hline 2015 & 10 & 14.5 & 2004 & 2 & 2.9 \\
\hline 2019 & 8 & 11.6 & 2007 & 2 & 2.9 \\
\hline 2011 & 4 & 5.8 & 2012 & 2 & 2.9 \\
\hline 2017 & 4 & 5.8 & 2014 & 2 & 2.9 \\
\hline 1983 & 3 & 4.3 & 1979 & 1 & 1.4 \\
\hline 2005 & 3 & $4 \cdot 3$ & 1994 & 1 & 1.4 \\
\hline 2009 & 3 & 4.3 & 1996 & 1 & 1.4 \\
\hline 2013 & 3 & 4.3 & 1998 & 1 & 1.4 \\
\hline 2018 & 3 & 4.3 & 2006 & 1 & 1.4 \\
\hline Topla & & & & 69 & 100.0 \\
\hline
\end{tabular}

Tablo 1'de tezlerin yazıldıkları yıla dağılımları yer almaktadır. Bu bulgulara göre en fazla tezin 2016 ylında " $\mathrm{f}=12$ - \%17,4" ile yazıldığı görülmektedir. 2016 yllında yazılan tez sayılarını 2015 yll " $\mathrm{f}=10$ \%14,5" izlemektedir. Daha sonra sirası ile 2019 " $\mathrm{f}=8-\% 11,6$ ", 2011 "f=4 - \%5,8”, 2017 " $\mathrm{f}=4-\% 5,8$ ", 1983 “f=3 - \%4,3", 2005 "f=3 - \%4,3", 2009 "f=3 - \%4,3", 2013 “f=3 - \%4,3", 2018 “f=3 - \%4,3”, 2020 "f=3 - \%4,3", 2004 "f=2 - \%2,9", 2007 "f=2 - \%2,9", 2012 "f=2 - \%2,9", 2014 "f=2 - \%2,9", 1979 "f =1 \%1,4”, 1994 “f=1 - \%1,4”, 1996 “f=1 - \%1,4”, 1998 “f=1 - \%1,4”, 2006 "f=1 - \%1,4” ylları gelmektedir.

Tablo 2. Tezlerin eğitim düzeyine göre dağlımları

\begin{tabular}{lcc}
\hline Tez Türü & $\mathbf{f}$ & \% \\
\hline Yüksek Lisans & 54 & 78.3 \\
Doktora & 11 & 15.9 \\
Tipta Uzmanlık & 4 & 5.8 \\
\hline Toplam & $\mathbf{6 9}$ & $\mathbf{1 0 0 , 0}$ \\
\hline
\end{tabular}

\footnotetext{
\begin{tabular}{r|l} 
Adres & Address \\
İstanbul Medeniyet Üniversitesi, Eğitim Bilimleri Fakültesi, Türkçe & İstanbul Medeniyet University, Faculty of Education Sciences,
\end{tabular} ve Sosyal Bilimler Eğitimi Bölümü, Türkçe Eğitimi ABD Cevizli $\quad$ Turkish and Social Scinces Education, Turkish Language Teaching Kampüsü, Kartal-İstanbul/TÜRKIYY $\quad$ Education, Cevizli Campus, Kartal-İstanbul /TURKEY e-posta: editor@rumelide.com 1 e-mail: editor@rumelide.com
} 
Tablo 2'de tezlerin eğitim düzeylerine göre dağılımları yer almaktadır. Bu bulgulara göre en fazla tezin yüksek lisans eğitim düzeyinde " $\mathrm{f}=54-\% 78,3$ " olduğu, yüksek lisans tezlerini ise " $\mathrm{f}=11-\% 15,9$ " ile doktora eğitim düzeyindeki tezlerinin izlediği, son sırada ise tıpta uzmanlık tezlerinin " $\mathrm{f}=4-\% 5,8$ " olduğu ortaya çıkmaktadır.

Tablo 3. Tezlerin yazıldıkları dillere göre dağılımları

\begin{tabular}{lcc}
\hline Dil & $\mathbf{f}$ & $\mathbf{\%}$ \\
\hline Türkçe & 62 & 89.9 \\
İngilizce & 7 & 10.1 \\
\hline Toplam & $\mathbf{6 9}$ & $\mathbf{1 0 0 . 0}$ \\
\hline
\end{tabular}

Tablo 3'te tezlerin yazıldıkları dillere göre dağılımları yer almaktadır. Bu bulgulara göre tezlerin en fazla Türkçe “f=62 - \%89,9", daha sonra İngilizce'de "f=7 - \%10,1" yazıldığı ortaya çımaktadır.

Tablo 4. Tezlerin tez danışmanlarının unvanlarına göre dağılımları

\begin{tabular}{lcc}
\hline Unvan & $\mathbf{f}$ & \% \\
\hline Profesör & 23 & 33.3 \\
Dr. Öğretim Üyesi & 23 & 33.3 \\
Doçent & 18 & 26.1 \\
Dr. & 2 & 2.9 \\
Prof. ve Dr. Öğretim Üyesi & 1 & 1.4 \\
Prof. ve Dr. & 1 & 1.4 \\
Doç. ve Dr. Öğretim Üyesi & 1 & 1.4 \\
\hline Toplam & $\mathbf{6 9}$ & $\mathbf{1 0 0 . 0}$ \\
\hline
\end{tabular}

Tablo 4'te tezlerin tez danışmanlarının unvanlarına göre dağılımı yer almaktadır. Bu bulgulara göre en tezlere en fazla profesör " $\mathrm{f}=23$ - \%33,3" ve doktor öğretim üyesi " $\mathrm{f}=23-\% 33,3$ " unvanındaki tez danışmanlarının danışmanlık yaptığı, bu tezleri sırası ile doçent " $\mathrm{f}=18-\% 26,1$ ", doktor " $\mathrm{f}=2-\% 2,9$ ", profesör ve doktor öğretim üyesi " $\mathrm{f}=1-\% 1,4$ ", profesör ve doktor " $\mathrm{f}=1-\% 1,4$ ", doçent ve doktor öğretim üyesi " $\mathrm{f}=1$ - \%1,4" unvanlarına sahip tez danışmanlarının danışmanlık yaptığı tezlerin takip ettiği görülmektedir.

Tablo 5. Tezlerin tez danışmanlarının cinsiyetine göre dağılımları

\begin{tabular}{lcc}
\hline Cinsiyet & f & \% \\
\hline Kadın & 41 & 59.4 \\
Erkek & 25 & 36.2 \\
Kadın ve Kadın & 2 & 2.9 \\
Kadın ve Erkek & 1 & 1.4 \\
\hline Toplam & $\mathbf{6 9}$ & $\mathbf{1 0 0 . 0}$ \\
\hline
\end{tabular}

Tablo 5’te tezlerin tez danışmanlarının cinsiyetine göre dağılımı yer almaktadır. Buna göre tez danışmanlarından kadın olanların " $\mathrm{f}=41$ - \%59,4", erkek olanların " $\mathrm{f}=25-\% 36,2$ " şeklinde sıralandığı, daha sonra ise kadın ve kadın " $\mathrm{f}=2$ - \%2,9"; kadın ve erkek " $\mathrm{f}=1$ - \%1,4" olmak üzere çift danışmanlı tezlerin yer aldığ görülmektedir.

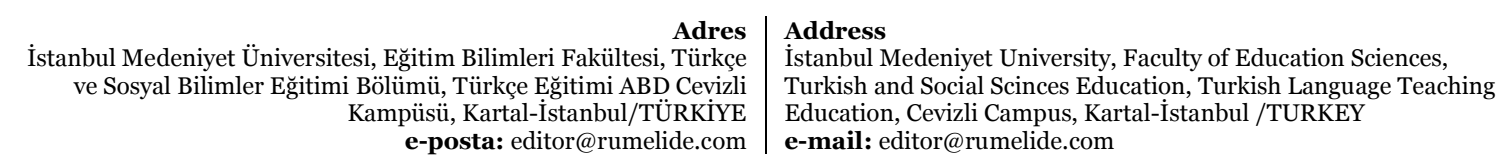


Examination of theses conducted on language development processes of individuals with special needs / İ. Erol; G. İlhan Ildız (pp. 559-574)

Tablo 6. Tezlerin tez yazarlarının cinsiyetine göre dağılımları

\begin{tabular}{lll}
\hline Cinsiyet & f & \% \\
\hline Kadın & 51 & 73.9 \\
Erkek & 18 & 26.1 \\
\hline Toplam & $\mathbf{6 9}$ & $\mathbf{1 0 0 . 0}$ \\
\hline
\end{tabular}

Tablo 6'da tezlerin tez yazarlarının cinsiyetine göre dağılımı yer almaktadır. Buna göre kadın tez yazarların " $\mathrm{f}=51$ - \%73,9" ve erkek yazarların " $\mathrm{f}=18$ - \%26,1" şeklinde sıralandığı görülmektedir.

Tablo 7. Tezlerin yazıldıkları üniversitelere göre dağılımları

\begin{tabular}{|c|c|c|c|c|c|}
\hline Üniversite & f & $\%$ & Üniversite & $\mathbf{f}$ & $\%$ \\
\hline Hacettepe & 14 & 20.3 & Bahçeşehir & 1 & 1.4 \\
\hline Ankara & 10 & 14.5 & $\begin{array}{l}\text { Necmettin } \\
\text { Erbakan }\end{array}$ & 1 & 1.4 \\
\hline Turgut Özal & 6 & 8.7 & Biruni & 1 & 1.4 \\
\hline Dokuz Eylül & 4 & 5.8 & Nişantaşı & 1 & 1.4 \\
\hline Anadolu & 4 & 5.8 & Orta Doğu Teknik & 1 & 1.4 \\
\hline Gazi & 3 & $4 \cdot 3$ & Beykent & 1 & 1.4 \\
\hline Koç & 3 & $4 \cdot 3$ & Atatürk & 1 & 1.4 \\
\hline Selçuk & 2 & 2.9 & Başkent & 1 & 1.4 \\
\hline Marmara & 2 & 2.9 & $\begin{array}{l}\text { Gülhane Askeri } \\
\text { Tıp Fakültesi }\end{array}$ & 1 & 1.4 \\
\hline Maltepe & 2 & 2.9 & İnönü & 1 & 1.4 \\
\hline Ege & 2 & 2.9 & Sütçü İmam & 1 & 1.4 \\
\hline \multicolumn{2}{|c|}{ Ankara Yıldırım Beyazıt 2} & 2.9 & Gaziantep & 1 & 1.4 \\
\hline Kırklareli & 1 & 1.4 & Medipol & 1 & 1.4 \\
\hline Akdeniz & 1 & 1.4 & & & \\
\hline
\end{tabular}

$\begin{array}{lrr}\text { Toplam } & 69 & 100.0\end{array}$

Tablo 7'de tezlerin yazıldıkları üniversitelere göre dağılımları yer almaktadır. Buna göre en fazla tezin Hacettepe Üniversitesinde " $\mathrm{f}=14$ - \%20,3" yazıldı $\breve{g}$, Hacettepe Üniversitesini, Ankara Üniversitesinin " $\mathrm{f}=10$ - \%14,5" izlediği görülmektedir. Daha sonra sirasıyla Turgut Özal " $\mathrm{f}=6-\% 8,7$ ", Dokuz Eylül " $\mathrm{f}=4$ - \%5,8" Anadolu "f=4 - \%5,8", Gazi " $\mathrm{f}=3$ - \%4,3", Koç " $\mathrm{f}=3$ - \%4,3", Selçuk "f=2 - \%2,9", Marmara "f=2 - \%2,9", Maltepe= 2 - \%2,9", Ege " $\mathrm{f}=2$ - \%2,9", Ankara Ylldırım Beyazıt " $\mathrm{f}=2$ - \%2,9", Kurklareli " $\mathrm{f}=1$ \%1,4", Akdeniz " $\mathrm{f}=1$ - \%1,4", Bahçeşehir " $\mathrm{f}=1$ - \%1,4", Necmettin Erbakan " $\mathrm{f}=1$ - \%1,4", Biruni " $\mathrm{f}=1$ \%1,4", Nişantaşı " $\mathrm{f}=1$ - \%1,4", Orta Doğu Teknik " $\mathrm{f}=1$ - \%1,4", Beykent " $\mathrm{f}=1$ - \%1,4", Atatürk " $\mathrm{f}=1$ \%1,4", Başkent " $\mathrm{f}=1$ - \%1,4", İnönü " $\mathrm{f}=1$ - \%1,4", Kahramanmaraş Sütçü İmam "f=1 - \%1,4", Gaziantep "f=1 - \%1,4", Medipol Üniversitesi " $\mathrm{f}=1$ - \%1,4" ve Gülhane Askeri Tip Fakültesinin " $\mathrm{f}=1$ - \%1,4" yer aldığı görülmektedir.

Tablo 8. Tezlerin yazıldıkları enstitülere göre dağılımları

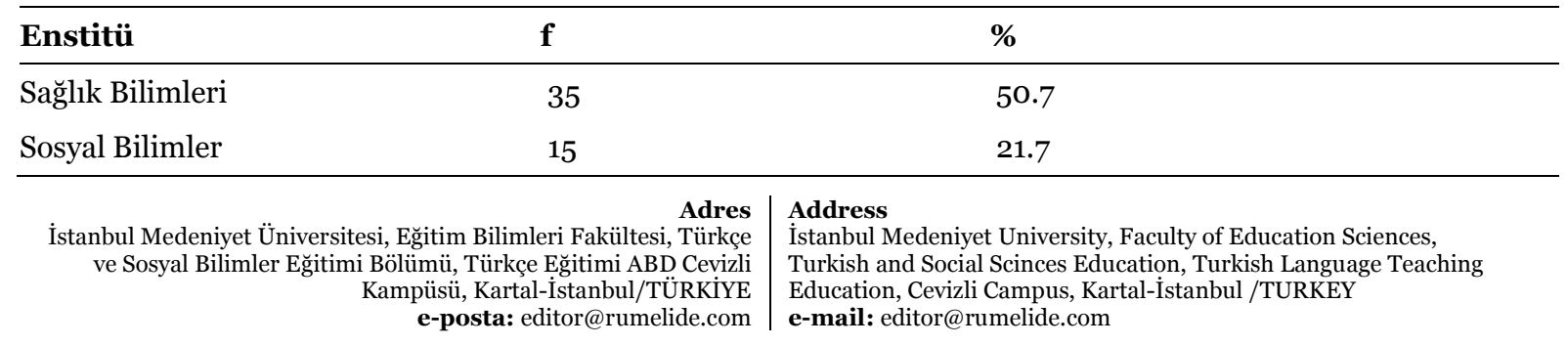




\begin{tabular}{lcc}
\hline Ĕ̆itim Bilimleri & 15 & 21.7 \\
Tıp Fakültesi & 3 & 4.3 \\
Diş Hekimliği Fakültesi & 1 & 1.4 \\
\hline Toplam & $\mathbf{6 9}$ & $\mathbf{1 0 0 . 0}$ \\
\hline
\end{tabular}

Tablo 8'de tezlerin yazıldıkları enstitülere göre dağılımları yer almaktadır. Buna göre en fazla tezin sağllk bilimleri enstitülerinde " $\mathrm{f}=35$ - \%50,7" yazıldığı görülmektedir. Sağlık bilimleri enstitülerini sosyal bilimler " $\mathrm{f}=15-\% 21,7$ " ve eğitim bilimleri enstitülerinin " $\mathrm{f}=15-\% 21,7$ " izlediği görülmektedir. Bu enstitüleri Tıp fakülteleri " $\mathrm{f}=3$ - \%4,3" ve Diş hekimliği fakülteleri " $\mathrm{f}=1$ - \%1,4" takip etmektedir.

Tablo 9. Tezlerin Yazıldıkları Anabilim Dalına Göre Dağılımları

\begin{tabular}{|c|c|c|c|c|c|}
\hline Anabilim Dalı & $\mathbf{f}$ & $\%$ & Anabilim Dalı & $\mathbf{f}$ & $\%$ \\
\hline Özel Eğitim & 12 & 17.4 & Klinik Psikoloji & 2 & 2.9 \\
\hline $\begin{array}{l}\text { Odyoloji ve Konuşma } \\
\text { Bozukluğu }\end{array}$ & 11 & 15.9 & Eğitim Bilimleri & 1 & 1.4 \\
\hline Çocuk Gelişimi & 9 & 13.0 & Güzel Sanatlar & 1 & 1.4 \\
\hline Kulak Burun Boğaz & 6 & 8.7 & İlköğretim & 1 & 1.4 \\
\hline Dil ve Konuşma Terapisi & 6 & 8.7 & Türkçe Eğitimi & 1 & 1.4 \\
\hline Yabancı Diller & 5 & 7.2 & Genel Psikoloji & 1 & 1.4 \\
\hline Psikoloji & 5 & 7.2 & Psikiyatri & 1 & 1.4 \\
\hline Ĕ̆itim Odyolojisi & 2 & 2.9 & Aile Hekimliği & 1 & 1.4 \\
\hline \multirow[t]{2}{*}{ Genel Bilim } & 2 & 2.9 & $\begin{array}{l}\text { Çocuk ve Ergen Ruh Sağlığı ve } \\
\text { Hastalıkları }\end{array}$ & 1 & 1.4 \\
\hline & & & Ağız Diş ve Çene Cerrahisi & 1 & 1.4 \\
\hline
\end{tabular}

\section{Toplam}

$69 \quad 100.0$

Tablo 9'da tezlerin yazıldıkları anabilim dallarına göre dağılımları yer almaktadır. Buna göre en fazla tezin özel eğitim anabilim dalında " $\mathrm{f}=12$ - \%17,4" yazıldı̆̆ görülmektedir. Özel eğitim anabilim dalını sırası ile Odyoloji ve Konuşma Bozukluğu " $\mathrm{f}=11$ - \%15,9", çocuk gelişimi " $\mathrm{f}=9$ - \%13,0", kulak burun boğaz " $\mathrm{f}=6$ - \%8,7" dil ve konuşma terapisi " $\mathrm{f}=6$ - \%8,7", yabancı diller " $\mathrm{f}=5-\% 7,2$ ", psikoloji " $\mathrm{f}=5$ \%7,2", eğitim odyolojisi " $\mathrm{f}=2$ - \%2,9", genel bilim " $\mathrm{f}=2$ - \%2,9", klinik psikolojisi " $\mathrm{f}=2$ - \%2,9", eğitim bilimleri " $\mathrm{f}=1$ - \% 1,4", güzel sanatlar=1 - \%1,4", ilköğretim " $\mathrm{f}=1$ - \% 1,4", Türkçe eğitimi " $\mathrm{f}=1$ - \% 1,4", genel psikoloji " $\mathrm{f}=1$ - \%1,4", psikiyatri " $\mathrm{f}=1$ - \%1,4", aile hekimliği " $\mathrm{f}=1$ - \% 1,4", çocuk ergen ruh sağlı̆̆1 ve hastalıkları " $\mathrm{f}=1$ - \% 1,4", ağız diş ve çene cerrahisi " $\mathrm{f}=1$ - \%1,4", anabilim dalları izlemektedir.

Tablo 10. Tezlerde kullanılan araştırma yöntemlerine göre dağılımlar

\begin{tabular}{lcc}
\hline Yöntem & f & \% \\
\hline Nicel & 61 & 88.4 \\
Nitel & 7 & 10.1 \\
Karma & 1 & 1.4 \\
\hline Toplam & $\mathbf{6 9}$ & $\mathbf{1 0 0 . 0}$ \\
\hline
\end{tabular}

Adres

İstanbul Medeniyet Üniversitesi, Eğitim Bilimleri Fakültesi, Türkçe ve Sosyal Bilimler Eğitimi Bölümü, Türkçe Eğitimi ABD Cevizli Kampüsü, Kartal-İstanbul/TÜRKIYE e-posta: editor@rumelide.com
Address

İstanbul Medeniyet University, Faculty of Education Sciences,

Turkish and Social Scinces Education, Turkish Language Teaching

Education, Cevizli Campus, Kartal-İstanbul /TURKEY

e-mail: editor@rumelide.com 
Tablo 10'da tezlerin kullanılan araştırma yöntemlerine göre dağılımları yer almaktadır. Buna göre tezlerde en fazla nicel araştırma yöntemleri " $\mathrm{f}=61$ - \%88,4" kullanılmıştır. Nicel araştırma yöntemlerini sırası ile nitel $(\mathrm{f}=7$ - \%10,1) ve karma $(\mathrm{f}=1$ - \%1,4) yöntemlerin takip ettiği görülmektedir.

Tablo 11. Tezlerin yazımında kullanılan araştırma modellerine göre dağılımlar

\begin{tabular}{lcc}
\hline Model & $\mathbf{f}$ & \% \\
\hline Tarama & 39 & 56.5 \\
Deneysel & 22 & 31.9 \\
Görüşme ve Gözlem & 3 & 4.3 \\
Görüşme & 2 & 2.9 \\
Gözlem & 2 & 2.9 \\
Tarama ve Görüşme & $\mathbf{1}$ & 1.4 \\
\hline Toplam & $\mathbf{6 9}$ & $\mathbf{1 0 0 . 0}$ \\
\hline
\end{tabular}

Tablo 11'de tezlerin kullanılan araştırma modellerine göre dağılımı yer almaktadır. Buna göre tezlerde en fazla tarama modelleri " $\mathrm{f}=39$ - \%56,5" kullanılmıştır. Tarama modellerini sırası ile deneysel ( $\mathrm{f}=22$ \%31,9), görüşme ve gözlem ( $\mathrm{f}=3-\% 4,3)$, görüşme ( $\mathrm{f}=2-\% 2,9)$, gözlem ( $\mathrm{f}=2-\% 2,9)$ ile tarama ve görüşme (f=1 - \%1,4) modelleri izlemektedir.

Tablo 12. tezlerde ele alınan özel gereksinim gruplarına göre dağılımlar

\begin{tabular}{lcc}
\hline Engel Durumu & f & $\mathbf{\%}$ \\
\hline İşitme Engeli & 18 & 26.1 \\
Kekemelik & 12 & 17.4 \\
Otizm Spektrum Bozukluğu & 7 & 10.1 \\
Zihinsel Engel & 6 & 8.7 \\
Artikülasyon Bozukluğu & 5 & 7.2 \\
Down Sendromu & 4 & 5.8 \\
Özgül Dil Bozukluğu & 4 & 5.8 \\
Gecikmiş Dil & 3 & 4.3 \\
Ses Bozukluğu & 2 & 2.9 \\
Dil ve Damak Yarıklı̆̆ı & 2 & 2.9 \\
Dil ve Konuşma Bozukluğu & 2 & 2.9 \\
Görme Engelli & 2 & 2.9 \\
Üstün Zekâ & 1 & 1.4 \\
Afazi & 1 & 1.4 \\
\hline Toplam & $\mathbf{6 9}$ & $\mathbf{1 0 0 . 0}$ \\
\hline
\end{tabular}

Tablo 12'de tezlerin ele alınan özel gereksinim gruplarına göre dağılımları yer almaktadır. Buna göre en fazla ele alınan özel gereksinim grubu işitme engeli $(\mathrm{f}=18$ - \%26,1)'dir. İşitme engelini sırası ile kekemelik ( $\mathrm{f}=12$ - \%17,4), otizm spektrum bozukluğu $(\mathrm{f}=7-\% 10,1)$, zihinsel engel $(\mathrm{f}=6-\% 8,7)$, artikülâsyon bozukluğu ( $f=5-\% 7,2)$, down sendromu ( $f=4-\% 5,8)$, özgül dil bozukluğu $(f=4-\% 5,8)$, gecikmiş dil $(\mathrm{f}=3-\% 4,3)$, ses bozukluğu $(\mathrm{f}=2-\% 2,9)$, dil ve damak yarıklı̆̆ $(\mathrm{f}=2-\% 2,9)$, dil ve 
konuşma bozukluğu ( $\mathrm{f}=2-\% 2,9)$, görme engelli $(\mathrm{f}=2-\% 2,9)$, üstün zekâ $(\mathrm{f}=1-\% 1,4)$ ve afazi $(\mathrm{f}=1$ $\% 1,4)$ grupları takip etmektedir.

Tablo 13. Tezlerde ele alınan konulara göre dağılımlar

\begin{tabular}{lll}
\hline Konu & f & \% \\
\hline Davranış Beceri Gelişim Değerlendirmesi & 25 & 36.2 \\
Program Materyal Eğitim Etkililiği & 17 & 24.6 \\
Normal Gelişim Gösteren ve Özel Gereksinimliı3 & & 18.8 \\
Birey Karşılaştırmaları & 5 & 7.2 \\
Yardımcı Teknoloji Etkililiği & 4 & 5.8 \\
Ebeveyn Uygulamaları ve Özellikleri & 2 & 2.9 \\
Ebeveyn Görüşleri & 2 & 2.9 \\
Özel Gereksinimli Birey Görüşleri & $\mathbf{1}$ & 1.4 \\
Yurtiçi-Yurtdışı Uygulama Karşılaştırmaları & $\mathbf{6 9}$ & $\mathbf{1 0 0 , \mathbf { 0 }}$ \\
\hline Toplam & $\mathbf{6 9}$ &
\end{tabular}

Tablo 13’te tezlerin ele alınan konulara göre dağılımları yer almaktadır. Buna göre tezlerde en fazla ele alınan konu davranış-beceri-gelişim değerlendirilmesi $(\mathrm{f}=25$ - \%36,2)' dir. Daha sonra sırası ile Program Materyal Eğitim Etkililiği ( $\mathrm{f}=17$ - \%24,6), Normal Gelişim Gösteren ve Özel Gereksinimli Birey Karşılaştırmaları ( $\mathrm{f}=13$ - \%18,8), Yardımcı Teknoloji Etkililiği ( $\mathrm{f}=5$ - \%7,2), Ebeveyn Uygulamaları ve Özellikleri ( $\mathrm{f}=4$ - \%5,8), Ebeveyn Görüşleri ( $\mathrm{f}=2$ - \%2,9), Özel Gereksinimli Birey Görüşleri ( $\mathrm{f}=2$ - \%2,9) ve Yurtiçi-Yurtdışı Uygulama Karşılaştırmaları $(\mathrm{f}=1$ - \%1,4) konuları yer almaktadir.

\section{Tartışma, sonuç ve öneriler}

$\mathrm{Bu}$ araştırmada özel gereksinimli bireylerin dil gelişim süreçleri ile ilgili yapılan lisansüstü tezler farklı kriterler doğrultusunda analiz edilmiştir. Bu kriterler tezlerin yazılmış oldukları yıllar, tezlerin yapılmış oldukları eğitim düzeyi ve yazıldıkları diller, tez danışmanlarının cinsiyeti ve unvanları, tez yazarlarının cinsiyetleri, tezlerin yazıldı̆̆ üniversiteler, enstitüler ve anabilim dalları, tezlerde kullanılan yöntem ve araştırma modelleri, tezlerde ele alınan özel gereksinim grupları ve konulardır. Araştırmaya "Yüksek Öğretim Kurumu Ulusal Tez" veri tabanından ulaşlan, araştırmanın amaçları doğrultusunda belirlenen "özel eğitimde dil gelişimi” kriterine uygun 69 lisansüstü tez dâhil edilmiştir. Lisansüstü tezler beş aşamalı içerik analizine tabi tutulmuştur.

Araştırma kapsamında özel gereksinimli bireylerin dil gelişim süreçleri ile ilgili yapılan tezlerin analizleri sonucunda alandaki tezlerin 1979 ile 2000 ylları arasında sıralandı̆̆ı belirlenmiştir. Sırasıyla 2016, 2015 ve 2019 yılları tezlerin en çok yazıldığı yıllardır. 1979, 1994, 1996, 1998 ve 2006 yıllarında ise yalnızca birer tez kaleme alınmıştır. Kiremit (2019), Türkiye'de okul öncesi eğitimde dil gelişimi alanında yapılan lisansüstü tezleri incelediği çalışmasında; yüksek lisans tez çalışmalarının özelikle 2009 yılı ve sonrasında çoğaldığını, 2004 yılı içerisinde ise okul öncesi dil gelişimi alanında yüksek lisans tezi yapılmadığı sonucunu elde etmiştir. 2004 ve 2013 yılları içerisinde ise 3 yl arayla doktora tez çalışmalarının gerçekleştiği sonucuna ulaşmış ve dil gelişimi alanında 2003-2005 yılları arasında okul öncesi dil gelişimi alanında hiçbir lisansüstü tez çalışmasının gerçekleşmediği ifade etmiştir. Karoğlu ve Çoban (2019) ise Türkiye'de okul öncesi eğitimde dil gelişimi ile ilgili yapılan lisansüstü tezleri incelediği çalışmada 1995 ve 2000 yılları kapsamında 3 tezin, 2001 ve 2005 yılları 
Examination of theses conducted on language development processes of individuals with special needs / İ. Erol; G. İlhan Ildız (pp. 559-574)

kapsamında 7 tezin, 2006 ve 2010 yılları kapsamında 15 tezin, 2011 ve 2016 ylları kapsamında ise 19 tezin yazılmış olduğu sonucuna ulaşmıştır. Alanyazında görüldüğü üzere dil gelişimi ile ilgili yazılan lisansüstü tezlerin yıllara göre değişkenlik gösterdiği özellikle 2011 yılı ve sonrasında alan ile ilgili tez yazım sayısının arttığı görülmektedir.

Tezler türlerine göre incelendiğinde sırasıyla yüksek lisans, doktora ve tıpta uzmanlık tezleri olarak sıralandıkları görülmektedir. Alpaydın ve Erol (2017), farklı bir alanında inceledikleri lisansüstü tezlerin 2 farklı eğitim alanında yazıldığı sonucuna ulaşmışlardır. Araştırmaları kapsamına aldıkları akademik çalışmalardan 24 tanesi (yaklaşık olarak \%30’u) doktora eğitimi alanında, 56 tanesi (yaklaşık olarak \%70’i yüksek lisans eğitimi alanında yazılmıştır. Yine Özenç ve Özenç (2013), üstün yetenekli öğrenciler ile ilgili yapılan lisansüstü tezleri inceledikleri çalışmada konuyla alakalı tezlerin 2007 ila 2010 yılları arasını \%26,3 gibi bir oran ile en fazla tez yazılan yıllar olarak dikkat çektiği sonucuna ulaşmıştır.

Tezlerin yazım dilleri incelendiğinde ise Türkçe ve İngilizce olmak üzere, iki dilde yazıldıkları, Türkçe dilinde yazılan tezlerin toplam tez sayısının yaklaşık \%9o'ını oluşturduğu göze çarpmaktadır. Aydın, Slevitopu ve Metin (2018) sınıf yönetimi alanındaki lisansüstü tezleri inceledikleri çalışmalarında, yazılan tezlerin \%94'lük kısmının Türkçe dilinde yazıldığını ve İngilizce dilinde üretilen lisansüstü tez çalışmalarının sınırlı kaldığını ortaya çıkarmışlardır. Bu durumun, Türkçe'nin anadil olması ve ülkemizdeki enstitülerin Türk dilinde eğitim vermesinden kaynaklandığı düşünülmektedir

Araştırma kapsamında incelenen tezlerin tez danışmanlarının unvanları incelendiğinde en fazla profesör ve doktor öğretim üyesi unvanlarına sahip tez danışmalarının bulunduğu, doçent unvanına sahip tez danışmanların da ikinci sırada yer aldığı belirlenmiştir. Özenç ve Özenç (2013), Türkiye'de üstün yetenekli öğrenciler ile alakalı yazılan 38 adet lisansüstü tezi yöneten danışman unvanlarını inceledikleri çalışmalarında profesörler ve yardımcı doçentlerin toplam \%73,6 oranında olduğu ve bunları sırası ile doçentlerin \%18,4 oran ile takip ettiğini dile getirmiştir. Alpaydın ve Erol (2017) ise lisansüstü araştırmalardaki tez danışmanlarının unvanlarını da kriter olarak inceledikleri çalışmalarında incelenen tezlerin danışmanlarının \% 66,25 oranla profesör, \%22,5 oranla yardımcı doçent olduğu sonucuna ulaşmışlardır. Bu bağlamda lisansüstü tez danışmanlarının alanyazında da görüldüğ̈̈ üzere en çok profesörler ve doktor öğretim üyelerinden oluştuğunu dile getirebiliriz.

Tez danışmanlarının cinsiyetine göre dağılımları incelendiğinde kadın danışmanların, toplam danışman sayısının \%50'sinden fazlasını oluşturduğu görülmektedir. Daha sonra erkek danışmanlar sıralamada yer almaktadır. Çift danışmanlı tezler ise toplamda 3 tane olup, yazar cinsiyetleri kadınkadın ve erkek-kadın şeklindedir. Alpaydın ve Erol (2017) araştırmalarında lisansüstü eğitim seviyelerindeki tez danışmanlarının cinsiyetlerini incelediklerinde, 24 kadın, 56'sının ise erkek olduğu sonucuna varmışlardır. Bu sonuçlar göstermektedir ki, lisansüstü tez danışmanlarının cinsiyet dağılımları, seçilen konuya, alana vb. kriterlere göre değişkenlik gösterebilmektedir.

Tez yazarlarının cinsiyetleri incelendiğinde, özel gereksinimli bireylerin dil gelişim süreçleri ile ilgili tezlerin danışmanlarının cinsiyetlerinde olduğu gibi, kadın yazarların erkek yazarlara göre daha ağırlıkta olduğu belirlenmiştir. Bıkmaz ve Arkadaşları (2013) ise farklı bir eğitim alanında doktora araştırması ortaya koyan araştırmacıların cinsiyet bağlamında sayılarını incelediğinde birbirleriyle yakın sayılara ulaşmıştır. Alpaydın ve Erol (2017) ise eğitim ile ilgili farklı bir araştırmada, çalışmaları gerçekleştiren araştırmacıların ve tez danışmanlarının cinsiyetleri hususunda; erkek araştırmacıların

Adres

İstanbul Medeniyet Üniversitesi, Eğitim Bilimleri Fakültesi, Türkçe ve Sosyal Bilimler Eğitimi Bölümü, Türkçe Eğitimi ABD Cevizli Kampüsü, Kartal-İstanbul/TÜRKIYE e-posta: editor@rumelide.com
Address

Istanbul Medeniyet University, Faculty of Education Sciences,

Turkish and Social Scinces Education, Turkish Language Teaching

Education, Cevizli Campus, Kartal-İstanbul /TURKEY

e-mail: editor@rumelide.com 
daha çok lisansüstü tez yazdıklarını ifade etmektedir. Bu sonuçlar, lisansüstü tez çalışmalarında cinsiyet yoğunluklarının, seçilen konulara göre değişkenlik gösterebileceğini açıklamaktadır.

Tezlerin yazıldıkları üniversiteler bağlamındaki bulgularda; üniversitelerin de çeşitlilik gösterdiği, 28 farklı üniversite bünyesinde özel gereksinimli bireylerin dil gelişimleri ile ilgili tez yazıldığı ortaya çlkmaktadır. Bu üniversitelerin başında sırası ile Hacettepe, Ankara ve Turgut Özal Üniversiteleri gelmektedir. Kiremit (2019) dil gelişimi üzerine yazılmış lisansüstü tezleri incelediği araştırmasında, bu düzeyde yazılan tezlerin sınırlı sayılabilecek illerde yazıldı̆̆ını ifade etmektedir. Çalışmasında lisansüstü tezlerin büyük bir bölümünün Ankara'da (8) sırası ile Bursa (4), İstanbul (3) ve Konya (3) gibi büyükşehir bünyesinde gerçekleştirildiği görülmektedir. Tezlerin bu illerde üretilmesinin nedenin, bu illerde özel eğitim ile ilgili bölümleri olan üniversitelerin bulunması olduğu düşünülmektedir.

Tezlerin yazıldığı enstitüler değerlendirildiğinde sağlık bilimleri enstitülerinde yazılan tezlerin toplam tez sayısının \%5o'sinden fazla olduğu görülmektedir. Sağlık bilimleri enstitülerini ikinci sırada sosyal bilimler ve eğitim bilimleri enstitüleri takip etmektedir. Aral vd., (2015), çocuk gelişimi alanındaki lisansüstü tezleri inceledikleri çalışmada, tezlerin genellikle $\% 38,81$ gibi büyük bir oranla Sağllk Bilimleri Enstitülerinde yazıldığını, aynı zamanda \%26,49 oranla Eğitim Bilimleri Enstitüleri, \%18,89 gibi bir oranla Sosyal Bilimler Enstitüleri ve \%15,81 oranla da Fen Bilimleri Enstitülerinde yazıldıklarını ortaya çıarmışlardır. Dil gelişimini ön planda tutan çocuk gelişimi alanının üniversitelerdeki akademik oluşumlarda başlangıçtan beri genellikle Sağlık Bilimleri Enstitülerinde kurulmuş olmalarının bu sonuçları etkilediğini de dile getirmektedirler. Özel gereksinimli bireyler interdisipliner çalışmalara konu olmaktadır. Fakat sağlık bilimleri ve eğitim bilimleri hem tanılama ve uygulama hem de araştırma bağlamında özel gereksinimli bireylerle çalışan disiplinlerdir. Bu nedenle çalışma grubundaki tezlerin sağlık bilimleri ve eğitim bilimleri enstitülerinde kaleme alınma slklıklarının daha yüksek olduğu söylenebilir.

Tezlerin yazıldığı anabilim dalları incelendiğinde, üniversiteler ve enstitüler gibi, anabilim dallarının da çeşitlilik gösterdiği ortaya çıkmaktadır. Anabilim dallarının dağılımları incelendiğinde sırasıyla özel eğitim, odyoloji ve konuşma bozukluğu ile çocuk gelişimi anabilim dallarının ilk sırada yer aldığı görülmektedir. Kiremit (2019) ise dil gelişimi üzerine yazılan lisansüstü tezlerin farklı anabilim dallarında bölümlerde yazıldığını ifade etmektedir. Temel eğitim bölümü, çocuk gelişimi bölümü, eğitim bilimleri bölümü, dil ve konuşma terapistliği bölümü, psikoloji bölümü, özel eğitim bölümü, Türkçe eğitimi bölümü ve yabancı dil eğitimi alanlardaki akademisyenlerin çalıştıkları ortaya çıkarılmıştır. Anabilim dallarının çeşitliliği göz önüne alındığında özel gereksinimli bireylerin interdisiplin çalışmalara konu olduğu söylenebilmektedir.

Araştırma bulguları incelendiğinde, tezlerde kullanılan araştırma yöntemleri değerlendirildiğinde \%88,4 gibi yüksek bir oran ile nicel araştırma yöntemlerinin kullanıldığı göze çarpmaktadır. Daha sonra sırasıyla nitel araştırma yöntemleri ve karma araştırma yöntemi gelmektedir. Çağlayan (2018); zihinsel engelli bireylerin dil gelişimlerinde etkili olan sanat eğitimi ile ilgili tezleri incelediği araştırmasında, lisansüstü tezlerin \%56,25 oranla (9) nicel araştırma yöntemleri, \%37,5 oranla (6) nitel araştırma yöntemleri, \%6,25 oranla (1) karma araştırma yöntemleri tercih edilerek yazıldıkları sonucuna ulaşmıştır. Yüksek lisans eğitim düzeyindeki tezlerde genellikle nicel araştırma yöntemleri, doktora düzeyindeki tezlerde ise genellikle nitel araştırma yöntemleri kullanıldığını ifade etmektedir. Araştırma bulguları ve konu ile ilgili literatürdeki diğer araştırmalar değerlendirildiğinde, ülkemizde lisansüstü çalışmalarda nicel araştırma yöntemlerinin sıklıkla tercih edildiği söylenebilmektedir. Nicel araştırma yöntemlerinin yanı sıra nitel ve karma araştırma yöntemlere yönelinmelidir.

Adres

İstanbul Medeniyet Üniversitesi, Eğitim Bilimleri Fakültesi, Türkce ve Sosyal Bilimler Eğitimi Bölümü, Türkçe Eğitimi ABD Cevizli Kampüsü, Kartal-İstanbul/TÜRKIYE e-posta: editor@rumelide.com
Address

İstanbul Medeniyet University, Faculty of Education Sciences,

Turkish and Social Scinces Education, Turkish Language Teaching

Education, Cevizli Campus, Kartal-İstanbul /TURKEY

e-mail: editor@rumelide.com 
Tezler araştırma modeline göre değerlendirildiğinde, toplam sayının \%56’sından fazlasında tarama modeli kullanıldı $\breve{g}$, tarama modelini deneysel modelde tasarlanan araştırmaların izlediği görülmektedir. Karoğlu ve Çoban (2019) araştırmalarında okul öncesi dönemlerde dil gelişimi konusu üzerine yazılmış olan lisansüstü 44 adet tezden 29'unun tarama modeli ile 15’inin de deneysel model ile gerçekleştirildiğini dile getirmektedirler. Yaptıkları analiz sonucunda da derleme türü ile yazılan teze rastlamadıklarını dile getirmektedirler. Kaytez ve Durualp (2014) ise, okul öncesi dönemde dil gelişiminde önemli rolü olan oyun konusu üzerine yapılan lisansüstü çalışmaları inceledikleri araştırmalarında örneklem olarak belirlenen lisansüstü tezlerin \%32'sinin tarama modeli, \%45'inin deneysel yöntemler, \%16'sının gözlem, \%5’inin görüşme ve \%2'sinin vaka çalışması yöntemleri ile yazıldığını ortaya çıkarmışlardır. Bu sonuç ile de inceledikleri tezler içerisinde tarama modeli ve deneysel yöntemlerin daha çok kullanıldığını ifade etmektedirler. Tarama ve deneysel modeller, nicel araştırma yöntemlerinde kullanılan yöntemlerdir. Araştırmalarda nicel araştırma yöntemlerinin sıklıkla kullanılmasının sonucu olarak, tarama ve deneysel model kullanımının ilk sıralarda yer alması beklenen bir sonuçtur.

Araştırma kapsamında analiz edilen tezlerin ele alınan özel gereksinim grubuna göre dağılımı değerlendirildiğinde işitme engeli ve kekemeliğin ilk iki sırada yer aldığ görülmektedir. Analizler sonucunda tespit edilen özel gereksinim gruplarının çeşitliliği de göze çarpmaktadır. Araştırma kapsamında dil gelişimi konusu spesifik olarak tercih edilmiştir. Bu nedenle dil ve konuşma alanında özel gereksinim olarak sınıflanan grupların sıklık yüzdesi yüksek çıkmıştır.

Tezler ele alınan konulara göre incelendiğinde ilk üç sırada davranış beceri gelişim değerlendirmesi, program materyal eğitim etkililiği ve normal gelişim gösteren ve özel gereksinimli birey karşılaştırması konularının yer aldığı ortaya çıkmaktadır. Tespit edilen konular, araştırma konusu ve amacı ile tutarlllık göstermektedir.

Araştırma sonuçları bağlamında özel gereksinimli bireylerin dil gelişim süreçleri üzerine gerçekleştirilebilecek çalışmalara ve potansiyel araştırmacılara şu öneriler sunulabilir:

- Kıyas yapılması açısından normal gelişim gösteren ve üstün yetenekli bireylerin dil gelişim süreçlerini inceleyen çalışmalar gerçekleştirilebilir.

- Alanyazında yer alan özel gereksinimli bireylerin dil gelişim süreçlerini inceleyen makalelerin de değerlendirilmesi yapılabilir.

- Türkiye'deki özel gereksinimli bireylerin dil gelişim süreçlerini inceleyen tezlerin yabancı dillerde de yazılması sağlanarak, uluslararası düzeyde okunurlukları arttırılabilir.

- Alanda daha fazla derinlemesine çalışmaların yapıldığı doktora seviyesinde lisansüstü tez çalışmalarının sayısı arttırılabilir.

- Dil gelişim süreçleri üzerine yazılacak tezlerde daha fazla nitel ve karma yöntemlerin kullanılması teşvik edilebilir.

\footnotetext{
Adres | Address

İstanbul Medeniyet Üniversitesi, Eğitim Bilimleri Fakültesi, Türkçe İstanbul Medeniyet University, Faculty of Education Sciences, ve Sosyal Bilimler Eğitimi Bölümü, Türkce Eğitimi ABD Cevizli Turkish and Social Scinces Education, Turkish Language Teaching Kampüsü, Kartal-İstanbul/TÜRKIYE $\quad$ Education, Cevizli Campus, Kartal-İstanbul /TURKEY e-posta: editor@rumelide.com $\mid$ e-mail: editor@rumelide.com
} 


\section{Kaynakça}

573 Sayılı Özel Eğitim Hakkında Kanun Hükmünde Kararname (1997). T.C. Resmi Gazete, 23011, 06 Haziran 1997. Erişim Tarihi: 18.11.2020. Erişim Adresi: https://www.mevzuat.gov.tr/ MevzuatMetin/4.5.573.pdf

Alpaydın, Y. ve Erol, İ. (2017). Türkiye'de eğitim ekonomisi alanında yapılan lisansüstü tezlerin incelenmesi. Marmara Üniversitesi Atatürk Eğitim Fakültesi Eğitim Bilimleri Dergisi, 45, s.23.41. DOI: 10.15285/maruaebd.292105

Aral, N., Findık Tanrıbuyurdu, E., Yurteri Tiryaki, A., Sağlam, M. ve Aysu, B. (2015). Türkiye'de çocuk gelişimi alanındaki lisansüstü tezlerin incelenmesi. Ankara Sağllk Hizmetleri Dergisi, 14(1), 715. DOI: https://doi.org/10.1501/Ashd_oooooo0103

Aydın, A., Slevitopu, A. ve Metin, K. (2018). Sınıf yönetimi alanındaki lisansüstü tezlerin incelenmesi. Abant İzzet Baysal Üniversitesi Ĕ̈itim Fakültesi Dergisi,18(1), 41-56. DOI: 10.17240/aibuefd.2018..-382251

Aydoğan, Y. ve Koçak, N. (2003). Okul öncesi çocukların dil gelişimine etki eden faktörlerin incelenmesi. Mili Ĕ̆itim Dergisi, 159. Erişim Adresi: https://dhgm.meb.gov.tr/ yayimlar/dergiler/Milli_Egitim_Dergisi/159/aydogan-kocak.htm

Baykoç Dönmez, N. (2010). Türkiye'de özel eğitim çalışmaları günümüzde yaşanan sorunlar ve çz̈züm önerileri. Baykoç, N. (Ed), Öğretmenlik programları için özel eğitim (s. 338-352). Ankara: Gündüz Eğitim ve.

Bıkmaz, F. H., Aksoy, E., Tatar, Ö. ve Altınyüzük, C. A. (2013). Eğitim programları ve öğretim alanında yapılan doktora tezlerine ait içerik çözümlemesi (1974-2009). Eğitim ve Bilim Dergisi, 38 (68), 288-303. Erişim Adresi: http://213.14.10.181/index.php/EB/article/view/1627

Büyüköztürk, Ş., Kılıç-Çakmak, E., Akgün, Ö.E., Karadeniz, Ş. ve Demirel, F. (2010). Bilimsel araştırma yöntemleri (6. Baskı). Ankara: Pegem.

Çağlayan, N. (2018). Türkiye'de zihinsel engellilerde sanat eğitimi ile ilgili lisansüstü tezlerin incelenmesi. Anadolu Journal of Educational Sciences International, 8(2), 403-418. DOI: https://doi.org/10.18039/ajesi.454586

Gönen, M. ve Arı, M. (1989). Anaokuluna giden dört-beş yaş çocuklarına resimli kitaplarla yapılan eğitimin dil geliş̧imine etkisinin incelenmesi. Eğitim ve Bilim, 13(72). Erişim Adresi: http://egitimvebilim.ted.org.tr/index.php/EB/article/view/5824/1951

Harley, A. T. (2001). The psychology of language, from data theory. New York. Psychology Press Ltd.

Karasar, N. (2009). Bilimsel araştırma yöntemi: kavramlar-ilkeler-teknikler. Ankara: Nobel Yayın Dağıtım.

Karoğlu, H. ve Çoban, A. E. (2019). Türkiye'de Okul Öncesi Eğitimde Dil Gelişimi ile İlgili Yapılan Lisansüstü Tezlerin İncelenmesi. Erzincan Üniversitesi Eğitim Fakültesi Dergisi, 21(1), 211229. DOI: https://doi.org/10.17556/erziefd.432657

Kayılı, G., Koçyiğit, S. ve Erbay, F. (2009). Montessori yönteminin beş-altı yaş çocuklarının alıcı dil gelişimine etkisinin incelenmesi. Selçuk Üniversitesi Türkiyat Araştırmaları Dergisi, 1(26), 347-355. Erişim Adresi: http://sutad.selcuk.edu.tr/sutad/article/view/442

Kaytez, N. ve Durualp, E. (2014). Türkiye'de okul öncesinde oyun ile ilgili yapılan lisansüstü tezlerin incelenmesi. Uluslararası Türk Eğitim Bilimleri Dergisi, 2014(2), 110-122. Erişim Adresi: https://dergipark.org.tr/tr/pub/goputeb/issue/7322/95830

Kiremit, R. F. (2019). Türkiye'de okul öncesi eğitimde dil gelişimi alanında yapılan lisansüstü tezlerin incelenmesi. Eskişehir Osmangazi Üniversitesi Sosyal Bilimler Dergisi, 2O, 159-174. DOI: https://doi.org/10.17494/ogusbd.548314

Özbay, M. ve Melanlığlu, D. (2008). Türkçe eğitiminde kelime hazinesinin önemi. Yüzüncü Yll Üniversitesi Ĕ̆itim Fakültesi Dergisi, 5(1), 30-45. Erişim Adresi: https://turkcede.org/images/ makaleler_pdf/dilyazilari/turkce-egitiminde-kelime-hazinesinin-onemi.pdf

\footnotetext{
Adres $\mid$ Address

İstanbul Medeniyet Üniversitesi, Eğitim Bilimleri Fakültesi, Türkçe $\quad$ İstanbul Medeniyet University, Faculty of Education Sciences, ve Sosyal Bilimler Eğitimi Bölümü, Türkce Eğitimi ABD Cevizli Turkish and Social Scinces Education, Turkish Language Teaching Kampüsü, Kartal-İstanbul/TÜRKIYE Education, Cevizli Campus, Kartal-İstanbul /TURKEY e-posta: editor@rumelide.com $\mid$ e-mail: editor@rumelide.com
} 
Özenç E. G. ve Özenç, M. (2013). Türkiye'de üstün yetenekli öğrencilerle ilgili yapılan lisansüstü eğitim tezlerinin çok boyutlu olarak incelenmesi. Türkiye Sosyal Araşttrmalar Dergisi, 171(171), 13-28. Erişim Adresi: http://dergipark.gov.tr/download/article-file/200625

Senemoğlu, N. (1989). Okulöncesi Eğitimde Dilin Önemi. Milli Eğitim Vakfi Dergisi. 4(14), 21-22.

Strauss, A. ve Corbin, J. (1990). Basics of qualitative research. Newbury Park: Sage.

Temel, F., Bekir, H. ve Yazıcı, Z. G. (2014). Erken çocuklukta dil edinimi. Ankara: Vize.

Turan, S., Karadağ, E., Bektaş, F. ve Yalçın, M. (2014). Türkiye'de eğitim yönetiminde bilgi üretimi: Kuram ve Uygulamada Eğitim Yönetimi Dergisi 2003-2013 yayınlarının incelenmesi. Kuram ve Uygulamada Eğitim Yönetimi Dergisi, 20(1), 93-119. DOI: https://doi.org/10.14527/ kuey.2014.005

Vendryes, J. V. (2001). Dil ve düşünce. Berke Vardar (çev.). İstanbul: Multilingual.

Vygotsky, L. S. (1985). Düşünce ve dil. Semih Koray (çev.), Ankara: Kaynak.

Yapıcı, Ş. (2006). Çocukta dil gelişimi. Journal of Human Sciences, 1(1), 1-17. Erişim Adresi: https://www.j-humansciences.com/ojs/index.php/IJHS/article/view/101

Yaralı, D. (2015). Öğretmen adaylarının özel gereksinimli bireylere yönelik tutumlarının bazı değişkenler açısından incelenmesi. Journal of Education Faculty,17(2), 431-455. DOI: https://doi.org/10.17556/jef.02712

Yıldırım, A. ve Şimşek, H. (2013). Sosyal bilimlerde nitel araştırma yöntemleri. (9. Baskı). Ankara: Seçkin. 